\title{
ANALISIS PERBANDINGAN KINERJA SAHAM (RETURN DAN RISK) PERUSAHAAN PERATA LABA DAN BUKAN PERATA LABA SEKTOR MANUFAKTUR DI BURSA EFEK JAKARTA
}

\author{
Juhli Edi Suranta Simanjuntak \\ Program Studi Magister Manajemen, Universitas Riau Pekanbaru \\ juhliedi@yahoo.com
}

\begin{abstract}
Abstrak : Riset ini didesain untuk menemukan praktek perataan laba di Indonesia. Perataan Laba dapat didefinisikan sebagai suatu tindakan manipulasi pelaporan laba yang tidak akurat pada periode tertentu (Bannister dan Newman - 1996). Hal utama dalam penelitian ini adalah terdapatnya perbedaan antara kinerja (Return \& Risk) perusahaan manufaktur yang terdapat di Bursa Efek Jakarta. Seratus Dua Puluh Empat perusahaan manufaktur terdaftar di Bursa efek Jakarta. Sample diklasifikasikan kedalam perusahaan perata laba dan bukan perata laba berdasarkan model Eckel (1981). Hasil menunjukan terdapat praktek perataan laba di perusahaan manufaktur yang terdaftar di Bursa Efek Jakarta. Statistik umum dan khusus digunakan untuk menguji hipotesis dalam penelitian ini. Statistik umum termasuk statistic descriptives, uji kenormalan data (Uji Lilliefors) dan uji populasi (Uji t). Rata-rata return untuk perusahaan bukan perata laba adalah 0,0301 dan untuk perusahaan perata laba adalah 0,0292. Rata-rata risk untuk perusahaan bukan perata laba adalah 1,1444 dan untuk perusahaan perata laba adalah 1,2107. Hasil uji kenormalan data populasi menunjukkan probability untuk variable Return adalah 0,0510 dan probability untuk variable Risk adalah 0,200 dimana keduanya lebih besar dari 0,05 sehingga dapat disimpulkan kedua variable berdistribusi normal. Hipotesis pertama mengemukakan tidak terdapatnya perbedaan antara Return antara perusahaan perata laba dan bukan perata laba yaitu diuji dengan menggunakan t-test dimana probability adalah 0,126 dan lebih besar dari 0,05. Hipotesis kedua mengemukakan tidak terdapatnya perbedaan antara Risk antara perusahaan perata laba dan bukan perata laba yaitu diuji dengan menggunakan t-test dimana probability adalah 0,590 dan lebih besar dari 0,05.
\end{abstract}

Kata Kunci : Kinerja Saham (Return dan Risk), Perata Laba, Bukan Perata Laba

Abstract : This research is designed to examine the income smoothing in Indonesia. Income smoothing can be defined as manipulation reported earnings so that they do not accuretely represent economic earnings at every point in the time (Bannister and Newman - 1996). The main issue invetigated in this research was the difference between the performance (Return \& Risk) of public manufacturing companies stocks in Indonesia. One Hundred Twenty four listed manufacture companies in the Jakarta Stock Exchange. The samples was than classified into earnings into smoother and non smoother using Eckel's model (1981). The results showed that there was income smoothing practiced by companies listed in JSX. Common and special statistical tests according to the hypotheses were used in the research. Common statistic includes descriptive statistics, normality data tests (Lilliefors test) and population tests (t-Test). Average 
return for non-smoother was 0,0301 and for smoother was 0,0292. Average risk for nonsmoother 1,1444 and for smoother 1,2107. All kinds of common statistical tests show probability for Return was 0,0510 and the probability for Risk was 0,200 which both are more than 0,05 these are concluded that the data were distributed normally. The first hypothesis whether there was not return difference between smoother \& non-smoother. It was tested with $t$ test and probability was 0,126 and so more than 0,05. The second hypothesis examined whether there was not risk difference between the risk between smoother \& non-smoother It was tested with t-test and probability was 0.590 and so more than 0.05 .

Keywords : Stock Performance (Return and Risk), income smoothing, non-income smoothing

\section{PENDAHULUAN}

\section{Latar Belakang}

Dengan semakin pesatnya perkembangan pasar modal di Indonesia dewasa ini, maka peranan laporan keuangan menjadi sangta penting. Bagi investor, informasi akuntansi merupakan data dasar dalam melakukan analisis saham serta untuk memprediksi prospek earning di masa mendatang. Perataan laba menjadi suatu hal yang merugikan investor karena investor tidak akan memperoleh informasi yang akurat mengenai laba untuk mengevaluasi tingkat pengembalian dan varian dari portofolionya bila terdapat praktik perataan laba. Tindakan perataan laba mengakibatkan pengungkapan dalam laporan keuangan menjadi tidak memadai. Den gan mempertimbangan bahwa praktirk perataan laba dapat mnyediakan sinyal yang meningkatkan akurasi prediksi laba, maka penelitian ingin melihat bagaimana reaksi pasar terhadap pengumuman informasi laba yang dilakukan oleh perusahaan yang melakukan praktik perataan laba dan apakah praktik perataan laba yang dilakukan berhasi meredam besarnya reaksi pasar ketika perusahaan mengumumkan labanya.

\section{Batasan Penelitian}

a. Batasan Waktu
Penelitian ini memiliki batasan pengambilan data selama tahun $1999 \mathrm{~s} / \mathrm{d}$ 2004.

b. Batasan Daerah

Daerah penelitian ini mencangkup perusahaan go public yang terdaftar di Bursa Efek Jakarta.

c. Batasan Aspek

Bidang kajian ini adalah manajemen keuangan dengan penekanan pembahasan kepada analisis tindakan perataan laba dan kinerja saham.

d. Batasan Lain Merupakan batasan bersifat teknis, yakni menyangkut waktu, biaya, dan tenaga.

\section{Perumusan Masalah}

1) Apakah terdapat perbedaan signifikan antara return saham pada perusahaan perata laba dan perusahaan bukan perata laba?

2) Apakah terdapat perbedaan signifikan antara risk saham pada perusahaan perata laba dan perusahaan bukan perata laba?

\section{Tujuan Penelitian}

Untuk memperoleh bukti empiris mengenai ada tidaknya perbedaan signifikanantara kinerja saham (return \& risk) pada perusahaan perata laba dan perusahaan bukan perata laba. 


\section{Hipotesis}

$\mathrm{HO}_{1}$ : Tidak terdapat perbedaan signifikan antara return saham pada perusahaan perata laba dan perusahaan bukan perata laba.

$\mathrm{HI}_{1}$ : Terdapat perbedaan signifikan antara return saham pada perusahaan perata laba dan perusahaan bukan perata laba.

$\mathrm{HO}_{2}$ : Tidak terdapat perbedaan signifikan antara risk saham pada perusahaan perata laba dan perusahaan bukan perata laba.

$\mathrm{HI}_{2}$ : Terdapat perbedaan signifikan antara risk saham pada perusahaan perata laba dan perusahaan bukan perata laba.

\section{Kerangka Konseptual}

Kerangka konseptual dalam penelitian ini dapat digambarkan sebagai berikut:

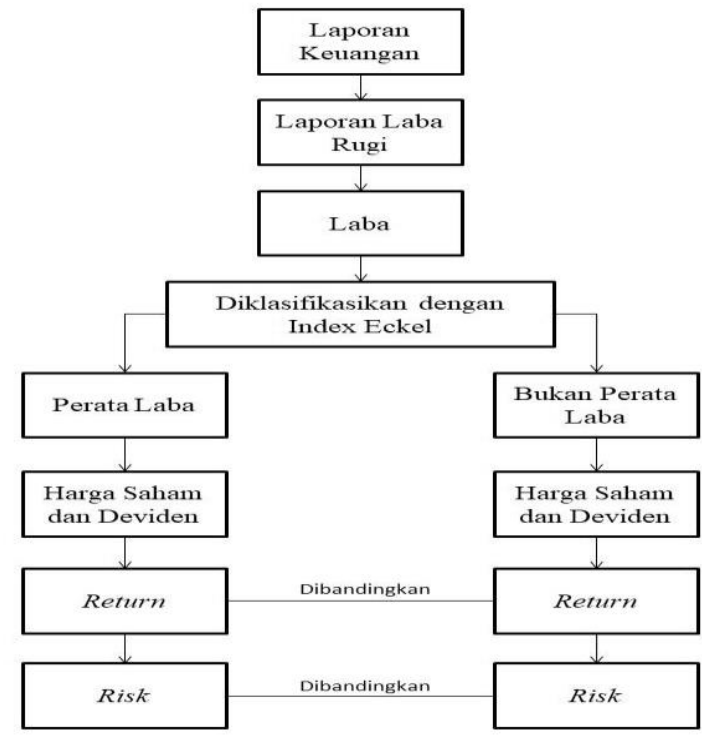

\section{METODE PENELITIAN}

\section{Populasi Penelitian}

Perusahaan yang menjadi populasi adalah perusahaan manufaktur yang terdaftar di Bursa Efek Jakarta, kecuali perusahaan jenis industri perbankan dan keuangan, sesuai dengan pengklasifikaasian Indonesian Capital Market Directory. Perusahaan yang memenuhi kriteria adalah sebanyak 124 perusahaan manufaktur yang kemudian dibagi menjadi dua yakni perusahaan perata laba dan perusahaan bukan perata laba dengan menggunakan indeks Eckel.

\section{Jenis Data Dan Sumber Data}

Penelitian ini menggunakan data skunder perusahaan manufaktur yang terdapat di Bursa Efek Jakarta dan sumber data diperoleh dari Indonesian Capital Market Directory.

\section{Pengukuran Variable}

1) Perata Laba (Income Smoothing)

$$
\mathrm{CV} \Delta \mathrm{S} \text { atau } \mathrm{CV} \Delta \mathrm{I}=\sqrt{\frac{\sum(\Delta \mathrm{I}-\Delta \overline{\mathrm{X}})^{2}}{\mathbf{n}-\mathbf{1}}}
$$

\section{2) Kinerja Saham Perusahaan}

a. Return Saham

$$
\mathrm{R}_{\mathrm{t}}=\frac{\left(\mathrm{P}_{\mathrm{t}}-\mathrm{P}_{\mathrm{t}-1}\right)+\mathrm{D}_{\mathrm{t}}}{\mathrm{P}_{\mathrm{t}-1}}
$$

b. Risk Saham

$$
\mathrm{R}_{\mathrm{i}}=\alpha_{\mathrm{i}}+\beta_{\mathrm{i}} \mathrm{R}_{\mathrm{m}}+\varepsilon_{\mathrm{i}}
$$

\section{Metode Analisis Data}

Prosedur pengujian hipotesis dalam penelitian ini adalah sebagai berikut:

a. Melakukan uji statistik secara umum yaitu statistik deskriptif yang digunakan untuk menggambarkan profil data sample.

b. Selanjutnya melakukan uji kenormalan data dengan uji One sample Kolmogorov-Smirnov test.

c. Jika data berdistribusi normal maka prosedur pengujian yang dilakukan selanjutnya adalah:

1) Melakukan Uji F (Uji Lavene)

2) Melakukan Uji t untuk 2 sampel independen 
d. Jika data berdistribusi normal maka pengujian dilakukan dengan menggunakan uji non parametrik MannWhitney $\mathrm{U}$ test.

\section{HASIL DAN PEMBAHASAN}

\section{Deskripsi Hasil Penelitian}

Adapun banyaknya perusahaan yang diambil sebagai populasi dalam penelitian ini adalah 124 perusahaan. Kemudian seluruh populasi tersebut diklasifikasikan kedalam kelompok perata laba dan bukan perata laba dengan cara menggunakan indeks Eckel. Hasil dari perhitungan tersebut didapatkan bahwa sejumlah 48 perusahaan diindikasikan melakukan perataan laba, dan sisanya ada sejumlah 76 perusahaan diindikasikan tidak melakukan perataan laba.

\section{Deskripsi Kinerja Saham Perusahaan}

a. Rata-rata return perusahaan perata laba dan bukan perata laba

Berdasarkan data tampak rata-rata return tertinggi selama periode penelitian diraih oleh PT. Sierad Produce Tbk yaitu sebesar 0,1516. Sedangkan PT. Cahaya Kalbar Tbk merupakan perusahaan yang memiliki rata-rata return terendah selama periode penelitian yaitu $-0,0180$.

\section{b. Risk perusahaan perata laba dan bukan perata laba}

Berdasarkan data memperlihatkan bahwa selama periode penelitian ßeta terbesar diraih oleh PT. Metrodata Electronic Tbk. Dan ßeta terkecil diraih oleh PT. Tira Austenite Tbk sebesar 0,3788 . c. Perbandingan kinerja saham perusahaan perata laba dan bukan perata laba

\begin{tabular}{|l|c|c|}
\hline \multicolumn{1}{|c|}{ Keterangan } & $\begin{array}{c}\text { Bukan } \\
\text { Perata Laba }\end{array}$ & Perata Laba \\
\hline Jumlah & 76 & 48 \\
\hline Rata-rata return & 0,0301 & 0,0292 \\
\hline Rata-rata & 1,1444 & 1,2107 \\
\hline
\end{tabular}

Dari perbedaan yang dihasilkan antara kedua kelompok perusahaan tersebut menggambarkan bahwa kinerja saham yang diukur dari return dan risk yang dihasilkan oleh perusahaan perata laba menghasilkan return yang lebih kecil namun memilikinilai risk yang lebih besar jika dibandingkan dengan perusahaan bukan perata laba.

\section{d. Pembuktian hipotesis}

Dari uraian sebelumnya telah dijelaskan gambaran perbandingan masing-masing variabel yang digunakan dalam penelitian ini antara perusahaan perata laba dan bukan perata laba. Gambaran tersebut akan digunakan sebagai pijakan untuk menganalisa model dan membuktikan hipotesa yang diajukan. Meskipun dari gambaran tersebut ditemukan adanya perbedaan, namun perlu dibuktikan dengan pengujian statistik perbedaan yang ada pada masing-masing variabel.

e. Uji kenormalan data

\begin{tabular}{|c|l|c|c|c|}
\hline No & Variabel & $\begin{array}{c}\text { Asymp. } \\
\text { Sig. } \\
(2 \text {-tailed })\end{array}$ & Ket. & $\begin{array}{c}\text { Hasil } \\
\text { Pengujian }\end{array}$ \\
\hline 1 & Return & 0,0510 & $\mathrm{P}>0,05$ & Normal \\
\hline 2 & Risk & 0,2000 & $\mathrm{P}>0,05$ & Normal \\
\hline
\end{tabular}

Dari tabel diatas terlihat bahwa untuk variabel return didapatkan nilai sebesar 0,0510 dan nillai itu lebih dari 0,05 sehingga dapat disimpulkan 
variabel return berdistribusi normal. Juga untuk variabel risk didapatkan nilai sebesar 0,2000 dan nillai itu lebih dari 0,05 sehingga dapat disimpulkan variabel risk juga berdistribusi normal.

\section{f. Uji t}

\section{- Pengujian variabel return}

\begin{tabular}{|l|c|c|c|c|}
\hline Variabel & Uji & $\begin{array}{c}\text { Asymp } \\
\text {.Sig. }\end{array}$ & Ket. & Keputusan \\
\hline Return & Uji t & 0,126 & P $>0,05$ & Ho diterima \\
\hline
\end{tabular}

Dari hasil pengujian dengan uji $\mathrm{t}$ untuk variabel return pada perusahaan perata laba dan bukan perata laba didapatkan nilai sebesar 0,126 . Nilai ini lebih besar dari 0,05 yang berarti Ho diterima. Dengan demikian dapat disimpulkan bahwa tidak terdapat perbedaan yang signifikan untuk rata-rata return antara perusahaan perata laba dan bukan perata laba.

\section{- Pengujian variabel risk}

\begin{tabular}{|l|c|c|c|c|}
\hline Variabel & Uji & $\begin{array}{c}\text { Asymp. } \\
\text { Sig. }\end{array}$ & Ket. & $\begin{array}{c}\text { Keputus } \\
\text { an }\end{array}$ \\
\hline Return & Uji t & 0,590 & $\mathrm{P}>0,05$ & $\begin{array}{c}\text { Ho } \\
\text { diterima }\end{array}$ \\
\hline
\end{tabular}

Dari hasil pengujian dengan uji $\mathrm{t}$ untuk variabel risk pada perusahaan perata laba dan bukan perata laba didapatkan nilai sebesar 0,590 . Nilai ini lebih besar dari 0,05 yang berarti Ho diterima. Dengan demikian dapat disimpulkan bahwa tidak terdapat perbedaan yang signifikan untuk rata-rata risk antara perusahaan perata laba dan bukan perata laba.

\section{PENUTUP}

\section{Kesimpulan}

Tujuan dari penelitian ini untuk menyajikan bukti empiris mengenai ada tidaknya perbedaan yang signifikan mengenai kinerja saham pada perusahaan manufaktur yang melakukan perataan laba dan tidak melakukan perataan laba yang terdaftar di Bursa Efek Jakarta. Dari analisis yang dilakukan peneliti ada beberapa kesimpulan yang dapat dikemukakan, antara lain:

a. Analisis data yang dilakukan menunjukkan bahwa praktek perataan laba ternyata dilakukan oleh perusahaan publik yang terdaftar di Bursa Efek Jakarta khususnya untuk jenis perusahaan manufaktur. Jumlah populasi dalam penelitian ini adalah 124 perusahaan dan hasil yang didapatkan adalah 48 perusahaan diindikasikan melakukan perataan laba dan 76 perusahaan diindikasikan tidak melakukan perataan laba.

b. Dari hasil uji statistik yang dilakukan menunjukkan bahwa bahwa tidak terdapat perbedaan signifikan untuk ratarata return dan risk antara perusahaan perata laba dan perusahaan bukan perata laba.

\section{Saran}

Saran yang disampaikan dalam penelitian ini adalah :

a. Bagi para investor hasil penelitian ini dapat bermanfaat dalam melakukan investasi pada saham perusahaan yang tercatat di Bursa Efek Jakartadimana temuan dalam penelitian ini menyatakan bahwa perusahaan perata laba memiliki rata-rata return yang lebih rendah 
dibandingkan perusahaan bukan perata laba.

b. Untuk penelitian selanjutnya, hendaknya meningkatkan cara mengukur atau mendeteksi tindakan perataan laba serta mengamatinya dalam konteks yang berbeda seperti periode waktu yang berbeda, siklus ekonomi, jenis, dan juumlah perusahaan yang dijadikan sampel.

c. Penelitian selanjutnya mengenai perataan laba dapat dilakukan dengan tidak hanya menggunakan indeks Eckel dalam mendeteksi kemungkinan perusahaan melakukan perataan laba namun juga dapat meneliti lebih lanjut mengenai kebijakan manajemen dan pemilihan metode akuntansi dalam periode tertentu yang memungkinkan perusahaan melakukan perataan laba.

\section{DAFTAR PUSTAKA}

Ayres, F. (1996). "Perception Earning Quality : What Managers Need to Know”. Management Accunting. Hal : 27-29.

Beck, T. (2000). Finance And The Sources Of Growth. Journal of Financial Economics 58, Hal 261-300.

Davies, A. (1999). "Startegic Approach to Corporate Governance". Gower Publishing Limited. England.

Eckel. (1981). The Income Smothing Hypothesis Revisited. Abacus. (June) : 28-40.

Fabozzy, F. (1999). Manajemen Investasi, Terjemahan. Jakarta: salemba 4.

Hermawan. (1999). "Analisis Faktor-Faktor Yang Berasosiasi Dengan Perilaku
Income Smoothing Oleh Perusahaan Publik Yang Terdaftar Di Bursa Efek Jakarta". Skripsi, Fakultas Ekonomi. Universitas Gajah Mada. Yogyakarta. Skripsi, Fakultas Ekonomi. Universitas Gajah Mada. Yogyakarta. 